UDC 664.644.9

DOI: 10.15587/2706-5448.2021.244239

Article type «Reports on Research Projects»

\section{Dlena Bilyk, Liudmyla Burchenko, Oksana Kochubei-Lytvynenko, Yulia Bondarenko}

\title{
DEVELOPMENT OF A RECIPE FOR A «SOLODOK" MULTICOMPONENT MIXTURE TO IMPROVE THE QUALITY OF PASTRIES
}

The object of research in this work is a baked product enriched with a mixture of sprouted grains, ground cinnamon, apple pectin, dry wheat gluten, ascorbic acid. Pastries occupy an important place in the production and sale of food products and have a high calorie content. To reduce the energy value of pastry products, it is proposed to replace wheat flour in the recipe with a mixture of germinated grains of wheat, oats, barley and corn. In this work, the properties of such mixtures were studied using the example of a mixture of the «CHOICE» company (Ukraine). The mixture of germinated grains of cereals of wheat, oats, barley and corn of this company is rich in dietary fiber, nonessential and irreplaceable amino acids, microelements and macroelements, vitamins.

It has been established that a rational substitution of premium wheat flour for a mixture of germinated grains in the recipe for pastry products is $50 \%$. Due to the germination process, a large amount of amylolytic and proteolytic enzymes accumulates in cereals, which impair the structural and mechanical properties of the crumb of pastry products, as a result of which the crumb of the product becomes sticky and wrinkled. The work was aimed at developing a multicomponent mixture to improve the quality of pastry products, the formulation of which includes a mixture of germinated grains. A «solodok» multicomponent mixture has been developed, which has a positive effect on the organoleptic and structural-mechanical properties of the product crumb. The mixture contains safe food additives and ingredients: ground cinnamon, dry wheat gluten, apple pectin, ascorbic acid. It has been established that the introduction of the «Solodok» multicomponent mixture into the dough leads to the replacement of the fermentation process with the stage of sedimentation. The use of a multicomponent mixture leads to an improvement in the organoleptic characteristics of rich products, an increase in the specific volume of products, and an improvement in the development of the porosity of products. Adding a mixture of sprouted grains and $a$ «Solodok» multicomponent mixture leads to a change in the traditional taste, the products acquire a pleasant aftertaste of sprouted cereals and cinnamon. The use of a mixture of germinated grains and $a \ll$ Solodok» multicomponent mixture in the recipe for pastry products leads to a decrease in the energy value of pastry products in comparison with the control.

Keywords: pastries, a mixture of germinated grains, multicomponent mixture, nutritional value, germinated cereals.

Bilyk, O., Burchenko, L., Kochubei-Lytoynenko, O., Bondarenko, Y. (2021). Development of a recipe for a «Solodok» multicomponent mixture to improve the quality of pastries. Technology Audit and Production Reserves, 6 (3 (62)), 47-52. doi: http://doi.org/10.15587/2706-5448.2021.244239

\section{Introduction}

The group of pastry includes products, the recipe of which includes a high content of sugar and fat. In finished products, the total amount of which should be $14 \%$ or more, the proportion of sugar and fat can be used to finish the surface of the product. Various ingredients are also used for the production of pastry, such as eggs, vanillin, raisins, poppy seeds, nuts, cinnamon, jam [1].

Buttery products attract consumers with their appearance, varied shape and weight, pleasant sweet taste and elastic, fine-pored crumbs. Along with this, baked goods are distinguished by a high energy value, which is a limiting factor for consumers who care about their health [2].
To reduce the energy value of pastry products, it is proposed to replace wheat flour in the recipe with a mixture of germinated grains of wheat, oats, barley and corn. In this work, the properties of such mixtures were studied using the example of a mixture of the «CHOICE» company (Ukraine). This mixture is a unique and innovative product. The special technology of steeping, germinating and drying allows not only to preserve its natural properties in the grain, but also to multiply them. Since in the germinated grain, all high molecular weight compounds of starch and proteins begin to uncouple and the transition into low molecular weight substances, which are characterized by high nutritional properties and are easily absorbed by the human body [3]. 
The disadvantage of using the mixture may be the deterioration of the structure of the crumb of products due to the influence of high amylolytic activity of germinated grains [4]. It is established in [5] that the use of flour from sprouted grain in bread technology leads to a change in the color of both the crust and crumb of the products to a more intense yellow color. There are also significant changes in the characteristics of the crumb of products, namely, the number of pores, the thickness of their walls increases, due to the higher viscosity of the dough and the weaker structure of gluten, the appearance of stickiness of the crumb of products is observed.

The authors of the study [6] found that the use of sprouted grains of oats, barley and wheat in an amount of 0.5 to $5.0 \%$ increases the specific volume of products. But at the same time, the stickiness of the crumb is observed, due to the high lipolytic and amylolytic activity of the germinated grains. The work established an improvement in the nutritional value of bakery products through the use of non-traditional raw materials.

In the scientific work [7], the technology of production of bakery products with the replacement of wheat flour with flour from sprouted wheat grains in dosages from 5 to $20 \%$ is considered. It was found that an increase in the amount of flour from sprouted grain in the formulation of bakery products leads to an increase in moisture content to $41.9 \%$, a decrease in acidity to $0.8 \%$, and a decrease in porosity to $72 \%$. Moreover, the maximum deviations from the control sample had products with a content of $20 \%$ grain.

Based on this, it is relevant to develop a multicomponent mixture to improve the quality of pastries, the formulation of which includes a mixture of germinated grains.

The object of research in this work is a baked product enriched with a mixture of sprouted grains, ground cinnamon, apple pectin, dry wheat gluten, ascorbic acid.

The aim of research is to develop a multicomponent mixture «Solodok» to improve the quality of pastries and prolong the freshness.

\section{Methods of research}

The studies used a mixture of sprouted grains of wheat, oats, barley and corn from «CHOICE» (Ukraine), as well as ground cinnamon, Polish-made apple pectin, dry wheat gluten (Finnish company «Leipurin» LLC), ascorbic acid produced.

To assess the quality of pastries with the addition of a mixture of germinated grains, cinnamon, apple pectin, dry wheat gluten, ascorbic acid, a laboratory baking test was carried out. The control was a butter product made according to the recipe [1]:

- wheat flour of the highest grade - $100 \mathrm{~kg}$;

- pressed baking yeast - $4.0 \mathrm{~kg}$;

- table salt - $1.5 \mathrm{~kg}$;

- white sugar - $15.0 \mathrm{~kg}$;

- sunflower oil - $10.0 \mathrm{~kg}$.

Pastry, enriched with a mixture of germinated grains of wheat, oats, barley and corn (MGG), was made from wheat flour of the highest grade in an accelerated way according to the recipe:

- wheat flour of the highest grade - $50 \mathrm{~kg}$;

- mixture of sprouted cereals - $50 \mathrm{~kg}$;

- pressed baking yeast - $4.0 \mathrm{~kg}$;
- table salt - $1.5 \mathrm{~kg}$;

- white sugar - $15.0 \mathrm{~kg}$;

- sunflower oil - $10.0 \mathrm{~kg}$.

The dough was kneaded in an Escher kneading machine (Italy) at first speed for 10 minutes. The dough was prepared in a straight dough way with a mass fraction of dough moisture $-34 \%$. The fermentation process was replaced by soaking for 15 minutes. The dough was processed manually, the dough pieces were allowed to stand in a rack at a temperature of $38 \pm 2{ }^{\circ} \mathrm{C}$ and a relative humidity of $78 \pm 2 \%$ until ready. The products were baked in a cabinet oven at a temperature of $180-200{ }^{\circ} \mathrm{C}$ with humidification of the baking chamber.

The composition of the multicomponent mixture «Solodok» includes: ground cinnamon, dry wheat gluten, apple pectin, ascorbic acid.

The quality of products was assessed by physical and chemical (specific volume, acidity) and organoleptic indicators (appearance, condition of the crust surface, structure of porosity, taste, aroma) [8]. The complex quality indicator was assessed by the point assessment of the quality of bakery products [8]. The comprehensive quality indicator took into account the quality indicators of bread, namely:

- specific volume;

- correctness of the form;

- crust color;

- staleness after 72 hours;

- condition of the crust surface;

- crumb color;

- porosity structure;

- form stability of hearth bread;

- rheological properties of the crumb;

- aroma of bread;

- taste of bread;

- chewiness of the crumb.

Each indicator is assessed on a five-point scale. Each point characterizes a certain level of quality: «5» - excellent; «4» - good; «3» - satisfactory; «2» - not satisfactory enough; «1»- unsatisfactory. To assess the quality of bakery products, determined by objective methods, they are calculated with an accuracy of 0.2 points, and the indicators of organoleptic evaluation (the arithmetic average of 3-5 tasters) are expressed with an accuracy of 0.1 points.

The quality of bakery products is assessed as the sum of points:

$$
K_{o}=\sum_{i=1}^{i=n} m_{i} x_{i},
$$

where $K_{o}-$ comprehensive assessment of the quality of bread, points; $m_{i}-$ coefficient of the weight of each indicator; $x_{i}$ - assessment of each indicator on a five-point scale; $i$ - indicator of the quality of the bread; $n-$ the number of indicators.

This formula takes place if $x \geq 2$, in the case of $x<2$, bread is recognized as unsatisfactory in quality, regardless of the amount of points. The quality of bakery products by the totality of all characteristics, taking into account the weight coefficients, is determined with an accuracy of 0.1 points. The highest possible quality score is 100 points.

The gas-holding capacity of the dough was determined by the change in the specific volume of $100 \mathrm{~g}$ of dough in the cylinder during the dough curing and the dough 
pieces standing [9]. The results of experimental studies were subjected to statistical processing using standard Microsoft Office software packages.

\section{Research results and discussion}

To determine the optimal dosage in the recipe for a pastry, a mixture of germinated grains of cereals of wheat, oats, barley and corn of the «CHOICE» Company (MGG) was carried out laboratory baked goods and examined the quality of finished products. Based on the data obtained, a complex quality indicator was calculated. The data obtained are shown in Table 1.

It has been found that when using a complete replacement of flour with MGG, products of unsatisfactory quality were obtained, which was confirmed by the low value of the integrated quality indicator. For further research, a MGG dosage in the amount of $50 \%$ was chosen instead of the mass of flour, since in terms of the specific volume, these products do not differ significantly from products in which the replacement is $25 \%$. It has been established that crumb crumbling and stickiness are observed when using MGGs; therefore, it is advisable to develop a multicomponent mixture to improve their quality.

To develop a multicomponent mixture, let's recommend use:

- to improve the structural and mechanical properties of the dough and to give the products taste and aroma - ground cinnamon [10];
- it is proposed to use apple pectin as a water-retaining additive [11, 12];

- it is proposed to use dry wheat gluten and apple pectin as a structurant [12, 13];

- to inhibit the action of amylolytic and proteolytic enzymes active in MGG, it is recommended to use ascorbic acid [14, 15].

The influence of each of the proposed ingredients and food additives on the quality of pastry was established to determine the rational dosage.

Based on the data obtained, a comprehensive quality indicator is calculated. The data are given in Table 2 .

On the basis of the obtained results of the rational dosage of ingredients and food additives (Table 2), the formulation of the «Solodok» multicomponent mixture was developed, which is intended to improve the quality of the baked product, the formulation of which includes $50 \%$ MGG (Table 3).

Subsequent researches concerned the influence of the «Solodok» multicomponent mixture on the technological process and quality of the rich product, the recipe of which includes MGG.

The prototypes were:

1 - bun (control without additives);

2 - bun, enriched with MGG in an amount of $50 \%$ instead of flour weight;

3 - bun, enriched with MGG in an amount of $50 \%$ instead of flour mass and with a developed «Solodok» multicomponent mixture.

The research results are presented in Table 4 and Fig. 1.

Table 1

The effect of a mixture of germinated grains on the technological parameters and quality indicators of pastry products, $n=3, p \geq 0.95, \delta=3-5 \%$

\begin{tabular}{|c|c|c|c|c|}
\hline \multirow{2}{*}{ Indicator } & \multirow{2}{*}{ Control (no additives) } & \multicolumn{3}{|c|}{ Added MGG, \% instead of flour mass } \\
\hline & & 25 & 50 & 100 \\
\hline \multicolumn{5}{|c|}{ Dough } \\
\hline $\begin{array}{l}\text { Titrated acidity, degree: } \\
\text { - initial } \\
\text { - final }\end{array}$ & $\begin{array}{l}1.0 \\
1.6\end{array}$ & $\begin{array}{l}1.2 \\
1.8\end{array}$ & $\begin{array}{l}1.6 \\
2.4\end{array}$ & $\begin{array}{l}2.1 \\
3.2\end{array}$ \\
\hline $\mathrm{CO}_{2}$ released during fermentation and proofing, $\mathrm{cm}^{3} / 100 \mathrm{~g}$ & 300 & 316 & 346 & 380 \\
\hline Dough ball spreading, \% & 90 & 86 & 80 & 76 \\
\hline Increase in dough volume in 4 hours. fermentation, \% & 148 & 127 & 118 & 110 \\
\hline Maturation time, min. & 60 & 60 & 55 & 50 \\
\hline \multicolumn{5}{|c|}{ Finished goods } \\
\hline Specific volume, $\mathrm{cm}^{3} / 100 \mathrm{~g}$ & 121 & 118 & 114 & 112 \\
\hline Crumb penetration, units appliance & 92 & 84 & 76 & 68 \\
\hline Surface condition & \multicolumn{4}{|c|}{ Smooth without cracks or tears } \\
\hline Crust color & Light golden & Golden & Light brown & Brown \\
\hline Crumb condition & Elastic & \multicolumn{3}{|c|}{ Jammed } \\
\hline Crumb color & Light & $\begin{array}{l}\text { Light with } \\
\text { a brown tint }\end{array}$ & \multicolumn{2}{|c|}{ Light brown } \\
\hline Porosity structure & \multicolumn{2}{|c|}{ Medium, uneven, thin-walled } & \multicolumn{2}{|c|}{ Small, uneven, thin-walled } \\
\hline Taste and aroma & $\begin{array}{l}\text { Peculiar to this product, without } \\
\text { foreign tastes and smells }\end{array}$ & \multicolumn{3}{|c|}{$\begin{array}{l}\text { Typical of this type of product with a malty flavor } \\
\text { of sprouted grains }\end{array}$} \\
\hline Comprehensive quality indicator & 85.6 & 80.2 & 76.6 & 70.2 \\
\hline
\end{tabular}

Note: $n$ - the number of repetitions of the study; $p$ - reliable probability; $\delta$ - гelative research еггог 
Comprehensive quality indicator of pastries with ground cinnamon, dry wheat gluten, apple pectin and ascorbic acid, $n=3, p \geq 0.95, \delta=3-5 \%$

\begin{tabular}{|c|c|c|c|c|c|c|c|}
\hline Indicator & Control (no additives) & Added MGG, $50 \%$ to the flour mass & \multicolumn{5}{|c|}{ Dosage (\%) by weight of flour } \\
\hline \multirow{12}{*}{ Comprehensive quality indicator } & \multirow{12}{*}{85.6} & \multirow{12}{*}{76.6} & \multicolumn{5}{|c|}{ Ground cinnamon } \\
\hline & & & 0.25 & 0.50 & 0.75 & 1.0 & 1.25 \\
\hline & & & 79.6 & 80.1 & 81.2 & 82.6 & 82.6 \\
\hline & & & \multicolumn{5}{|c|}{ Dry wheat gluten } \\
\hline & & & 0.25 & 0.50 & 0.75 & 1.0 & 1.25 \\
\hline & & & 80.6 & 82.4 & 84.2 & 87.1 & 87.3 \\
\hline & & & \multicolumn{5}{|c|}{ Apple pectin } \\
\hline & & & 0.25 & 0.50 & 0.75 & 1.0 & 1.25 \\
\hline & & & 79.5 & 80.1 & 81.0 & 82.4 & 82.3 \\
\hline & & & \multicolumn{5}{|c|}{ Ascorbic acid } \\
\hline & & & 0.02 & 0.04 & 0.06 & 0.08 & 0.10 \\
\hline & & & 80.8 & 81.6 & 81.6 & 81.5 & 81.4 \\
\hline
\end{tabular}

Note: $n$ - the number of repetitions of the study; $p$ - reliable probability; $\delta$ - relative research error; in cells with a gray color, the rational dosage of ingredients and food additives is indicated in accordance with the highest value of the integrated quality indicator

Table 3

The recipe for the «Solodok» multicomponent mixture

\begin{tabular}{|c|c|}
\hline Raw materials & The optimal dosage (\%) to the flour mass in the recipe for the «Curative» buns with $50 \%$ instead of the MGG flour mass \\
\hline Ground cinnamon & 1.0 \\
\hline Dry wheat gluten & 1.0 \\
\hline Apple pectin & 1.0 \\
\hline Ascorbic acid & 0.06 \\
\hline Total & 3.06 \\
\hline
\end{tabular}

Table 4

The impact of the "Solodak» multicomponent mixture on the technological process and quality of baked goods, $n=3, p \geq 0.95, \delta=3-5 \%$

\begin{tabular}{|c|c|c|c|}
\hline Indicators & $\begin{array}{l}\text { Contral without } \\
\text { additives - bun }\end{array}$ & $\begin{array}{c}\text { Bun, enriched with MGG } \\
\text { in an amount of } 50 \% \text { instead } \\
\text { of flour weight }\end{array}$ & $\begin{array}{l}\text { Bun, enriched with MGG in an amount of } 50 \% \\
\text { instead of flour mass and with a developed } \\
\text { "Solodok» multicomponent mixture }\end{array}$ \\
\hline \multicolumn{4}{|c|}{ Dough } \\
\hline Humidity, \% & \multicolumn{3}{|c|}{33.0} \\
\hline $\begin{array}{l}\text { Titrated acidity, degrees: } \\
\text { - initial } \\
\text { - final }\end{array}$ & $\begin{array}{l}1.0 \\
1.5\end{array}$ & $\begin{array}{l}2.5 \\
3.0\end{array}$ & $\begin{array}{l}2.5 \\
3.0\end{array}$ \\
\hline Maturation time, min. & 65 & 60 & 55 \\
\hline \multicolumn{4}{|c|}{ Finished goods } \\
\hline Specific volume, $\mathrm{cm}^{3} / 100 \mathrm{~g}$ & 121 & 115 & 120 \\
\hline Acidity, deg. & 1.5 & 3.0 & 3.0 \\
\hline Surface condition and color & $\begin{array}{l}\text { Smooth without cracks, } \\
\text { light golden color }\end{array}$ & \multicolumn{2}{|c|}{ Smooth without cracks, dark golden color } \\
\hline Crumb calor & Yellow brown & \multicolumn{2}{|r|}{ Light brown } \\
\hline Porosity structure & $\begin{array}{c}\text { Thin-walled, medium, } \\
\text { uneven, elastic }\end{array}$ & $\begin{array}{l}\text { Thin-walled, small, uneven, there is } \\
\text { sticking of the crumb characteristic of } \\
\text { a product made from sprouted grain }\end{array}$ & Thin-walled, medium, uneven, elastic \\
\hline Taste and aroma & $\begin{array}{c}\text { Characteristic of this type } \\
\text { of product }\end{array}$ & \multicolumn{2}{|c|}{ Pleasant taste and aroma, smell of sprouted cereals and cinnamon is felt } \\
\hline
\end{tabular}

Note: $n$ - the number of repetitions of the study; $p$ - reliable probability; $\delta$ - relative research error 


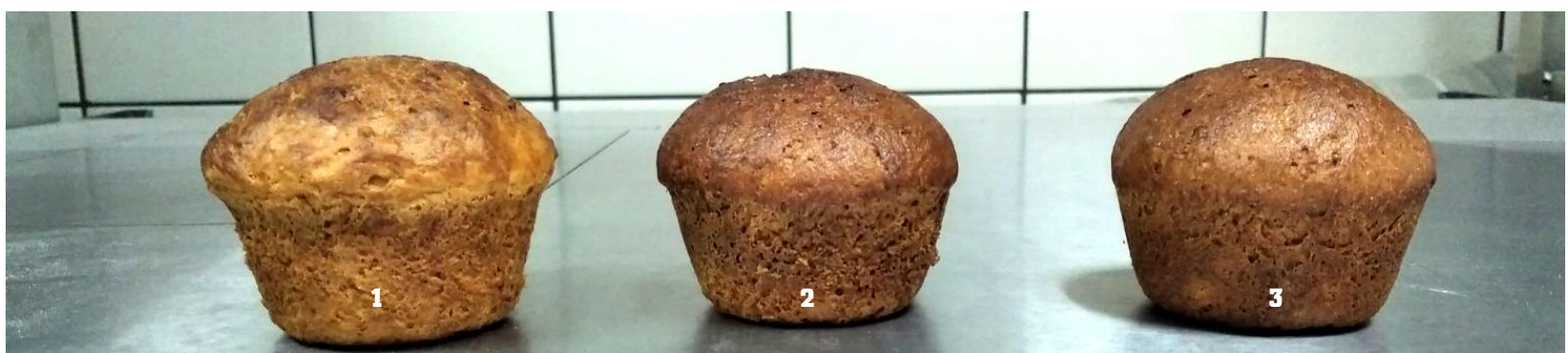

Fig. 1. Photo of finished products: 1 - control - butter product; 2 - bun with the addition of $50 \%$ MGG to the flour mass; 3 - «Lurative» bun with the addition of $50 \%$ MGG to the mass of flour with a "Solodok» multicomponent mixture

As a result of the studies carried out, it was found that when the MGG dosage in an amount of $50 \%$, instead of the flour mass, there is a deterioration in organoleptic quality indicators and structural and mechanical properties, which can be explained by the excessive activity of amylases. The specific volume in comparison with the control decreases by $5.2 \%$. The developed «Solodok» multicomponent mixture has a positive effect on the quality of the butter product. Due to the use of the developed multicomponent mixture, the specific volume of the rich product enriched with MGG increases to the size of the control sample, the structure of the porosity of the products is improved and the shape stability of the products is improved. The addition of MGG and the «Solodok» multicomponent mixture leads to a change in the traditional taste, the products acquire a pleasant aftertaste of sprouted cereals and cinnamon.

Based on the positive effect of the «Solodok» multicomponent mixture on the quality of pastries enriched with MGG, a recipe for the Curative bun was developed:

- wheat flour of the highest grade - $50 \mathrm{~kg}$;

- a mixture of sprouted cereals - $50 \mathrm{~kg}$;

- pressed baking yeast - $4.0 \mathrm{~kg}$;

- table salt - $1.5 \mathrm{~kg}$;

- white sugar - $15.0 \mathrm{~kg}$;

- sunflower oil - $10.0 \mathrm{~kg}$;

- multicomponent mixture «Sweet»- $3.06 \mathrm{~kg}$.

To determine the influence of MGG and the «Solodok» multicomponent mixture on the nutritional value of the bun, the chemical composition and energy value were calculated. The data obtained were compared with the control. When carrying out the calculations, reference data on the chemical composition of raw materials were used [16]. The results are presented in the Table 5 .

The results of calculations of the energy value show that as a result of replacing $50 \%$ of the premium flour with MGG in the recipe for rich products and the use of the «Solodok» multicomponent mixture, the energy value of $100 \mathrm{~g}$ of the product decreases. There is an increase in the content of dietary fiber, protein and a decrease in the number of bread units.

The use of a mixture of sprouted grains and a multicomponent mixture «Solodok» in the technology of rich products made from premium flour will lead to an increase in their cost.

The introduction of a new pastry product with a mixture of sprouted grains at bakeries will contribute to the expansion of the range of products.

The technology of the developed pastry product excludes the fermentation operation, which will lead to a reduction in the technological process, a decrease in the cost of fermentation and an increase in the yield of products.
Table 5

Chemical composition of $100 \mathrm{~g}$ of finished products

\begin{tabular}{|l|c|c|}
\hline \multicolumn{1}{|c|}{ Products composition } & $\begin{array}{c}\text { Control - } \\
\text { butter product }\end{array}$ & $\begin{array}{c}\text { Bun, enriched with MGG } \\
\text { in an amount of 50 \% } \\
\text { instead of flour mass and } \\
\text { with a developed «5olodok» } \\
\text { multicomponent mixture }\end{array}$ \\
\hline Proteins, g & 7.7 & 8.5 \\
\hline Fat, g & 7.8 & 8.0 \\
\hline of which saturated fatty acids & 0.9 & 5.9 \\
\hline Carbohydrates, g & 58.3 & 1.4 \\
\hline of which sugar & 1.2 & 5.0 \\
\hline Dietary fiber, g & 2.3 & 1.8 \\
\hline Ash, g & 1.4 & 1.0 \\
\hline Salt (calculated from sodium) & 1.0 & 321.4 \\
\hline Energy value, kcal & 334.4 & 4.4 \\
\hline Bread units, BU & 4.8 & \\
\hline
\end{tabular}

A limiting factor in the use of a mixture of germinated grains is their limited shelf life due to oxidative processes.

\section{Conclusions}

According to the results of experimental studies, a rational replacement in the recipe for pastry products of $50 \%$ wheat flour of the highest grade with a mixture of germinated grains of cereal crops of wheat, corn, barley and oats has been established. To improve the quality of these products, a «Solodok» multicomponent mixture has been developed, which includes $(\mathrm{kg})$ : dry wheat gluten - 1.0; apple pectin - 1.0; ground cinnamon - 1.0; ascorbic acid 0.006 . As a result of the use of the «Solodok» multicomponent mixture, the specific volume of the «Curative» bun increases in comparison with the pastry product, in which $50 \%$ of flour is replaced by a mixture of germinated grains by $4.3 \%$.

The recipe for the «Curative» bun was developed, which was awarded a second degree diploma at the «Special Purpose Bakery» competition held by the All-Ukrainian Association of Bakers.

The use of a mixture of sprouted grains and a «Solodok» multicomponent mixture in the recipe for pastry products leads to a decrease in the energy value of high-calorie pastry products by $4.0 \%$. 


\section{References}

1. Drobot, V. I. (2018). Dovidnyk z tekhnolohii khlibopekarskoho oyrobnytstva. Kyiv: ProfKnyha, 580.

2. Koryachkina, S. Ya., Matveeva, T. V. (2013). Funktsionalnye pischevye ingredienty $i$ dobavki dlya khlebobulochnykh $i$ konditerskikh izdelii. Saint Petersburg: GIORD, 628.

3. Miliutin, O. I., Varhanova, I. V., Potapenko, S. I. (2009). Pat No. 46340 UA. Sposib otrymannia biolohichno-aktyonoho produktu «proroshcheni zerna». MPK A23L 1/172. No. u200911217; declareted: 05.11.2009; published: 10.12.2009, Bul. No. 23.

4. Auerman, L. Ya. (2009). Tekhnologiya khlebopekarnogo proizvodstva. Saint Petersburg: Professiya, 416.

5. Kun, G. A. O., Yanxiang, L., Bin, T., Xiaohong, T., Duqin, Z., Liping, W. (2021). An insight into the rheology and texture assessment: The influence of sprouting treatment on the whole wheat flour. Food Hydrocolloids, 107248. doi: https://doi.org/ 10.1016/j.foodhyd.2021.107248

6. Mäkinen, O. E., Arendt, E. K. (2012). Oat malt as a baking ingredient - A comparative study of the impact of oat, barley and wheat malts on bread and dough properties. Journal of Cereal Science, 56 (3), 747-753. doi: http://doi.org/10.1016/ j.jcs.2012.08.009

7. Lebedenko, T. Ye., Pshenyshniuk, H. F., Sokolova, N. Yu. (2014). Tekhnolohiia khlibopekarskoho vyrobnytstva. Odesa: Osvita Ukrainy, 392.

8. Drobot, V. I. (2015). Tekhnokhimichnyi kontrol syrovyny ta khlibobulochnykh $i$ makaronnykh vyrobiv. Kyiv: NUKhT, 902.

9. Bondarenko, Y., Mykhonik, L., Bilyk, O., Kochubei-Lytvynenko, O., Andronovich, G., Hetman, I. (2019). Study of the influence of buckwheat flour and flax seeds on consumption properties of long-stored bakery products. EUREKA: Life Sciences, 4, 9-18. doi: http://doi.org/10.21303/2504-5695.2019.00973

10. Drevin, V. E., Kryuchkova, E. I., Kryuchkova, T. E. (2016) Biologicheskie aspekty primeneniya pektina pri proizvolstve pshenichnogo khleba. Vestnik agrarnoi nauki Dona, 2 (34), 37-41.

11. Imesin, A. (Ed.) (2010). Food Stabilisers, Thickeners and Gelling Agents. Oxford: Wiley-Blackweel, 258.

12. Kolpakova, V. V., Budantsev, E. V., Zaitseva, L. V., Studennikova, O. Yu., Vanin, S. V., Vasilenko, Z. V. (2010). Sukhaya pshenichnaya kleikovina: funktsionalnye svoistva, perspektivy primeneniya. Pischevaya promyshlennost, 4, 56-59. Available at: https://cyberleninka.ru/article/n/suhaya-pshenichnayakleykovina-funktsionalnye-svoystva-perspektivy-primeneniya

13. Martyanova, A., Pischugina, E. (2002). Vliyanie sukhoi pshenichnoi kleikoviny na khlebopekarnye svoistva muki. Khleboprodukty, 8, 14-17.

14. Bobyshev, K. A., Matveeva, I. V., Yudina, T. A. (2013). Vliyanie askorbinovoi kisloty na svoistva testa i kachestvo khleba. Pischevye ingredienty. Syre $i$ dobavki, 1, 52-55.

15. Miller, K. A., Hoseney, R. C. (1999). Effect of Oxidation on the Dynamic Rheological Properties of Wheat Flour-Water Doughs. Cereal Chemistry Journal, 76 (1), 100-104. doi: http:// doi.org/10.1094/cchem.1999.76.1.100

16. Skurikhin, I. M., Tutelyan, V. A. (Eds.) (2002). Khimicheskii sostav rossiiskikh pischevykh produktov. Moscow, 236.

$\triangle$ Olena Bilyk, PhD, Associate Professor, Department of Bakery and Confectionary Goods Technology, National University of Food Technologies, Kyiv, Ukraine, ORCID: http://orcid.org/0000-00033606-1254, e-mail: bilyklena@gmail.com

Liudmyla Burchenko, Postgraduate Student, Department of Bakery and Confectionary Goods Technology, National University of Food Technologies, Kyiv, Ukraine, ORCID: http://orcid.org/0000-00025413-961X

Oksana Kochubei-Lytoynenko, PhD, Associate Professor, Department of Milk and Dairy Technology, National University of Food Technologies, Kyiz, Ukraine, ORCID: http://orcid.org/0000-0003$0712-448 X$

Yulia Bondarenko, PhD, Associate Professor, Department of Bakery and Confectionary Goods Technology, National University of Food Technologies, Kyiv, Ukraine, ORCID: http://orcid.org/00000002-3781-5604

$\triangle$ Corresponding author 